\title{
Modelling organic matter dynamics in different soils
}

\author{
E. L. J. VERBERNE, J. HASSINK, P. DE WILLIGEN, J. J. R. GROOT \& \\ J. A. VAN VEEN
}

Institute for Soil Fertility Research, P.O. Box 30003, NL 9750 RA Haren, Netherlands

Received 16 February 1990; accepted 3 May 1990

\begin{abstract}
A mathematical model was developed to describe carbon (C) and nitrogen $(\mathrm{N})$ cycling in different types of soil, e.g. clay and sandy soils. Transformation rates were described by firstorder kinetics. Soil organic matter is divided into four fractions (including microbial biomass pool) and three fractions of residues. The fraction of active soil organic matter was assumed to be affected by the extent of physical protection within the soil, so was the soil microbial biomass. The extent of protection influenced the steady state level of the model, and, hence, the mineralization rates. The mineralization rate in fine-textured soils is lower than in coarsetextured soils; in fine-textured soils a larger proportion of the soil organic matter may be physically protected. The availability of organic materials as a substrate for microorganisms is not only determined by their chemical composition, but also by their spatial distribution in the soil. In future research, attention will be paid to the effects of soil structure and soil texture and to the spatial distribution of organic materials and their decomposers.
\end{abstract}

Keywords: model, soil organic matter, protection, mineralization

\section{Introduction}

Part of the nitrogen demand of plants is satisfied by uptake of inorganic nitrogen produced by mineralization of organic nitrogenous compounds in soil. The rate of mineralization depends on environmental conditions, such as moisture and oxygen status, carbon dioxide pressure, aeration, $\mathrm{pH}$, temperature (Swift et al., 1979), but also on soil type and agricultural practices, such as crop rotation and cultivation. The efficiency of mineralized nitrogen as part of the nitrogen supply of plants is at a maximum when the timing of release from organic matter is synchronized with that of plant uptake. Thus, to optimize management of nitrogen supply in agricultural systems, understanding of the dynamics of soil organic nitrogen turnover is necessary.

Mechanistic dynamic simulation models have proven to be useful for the study of soil organic matter dynamics; they help to integrate the fragmentary knowledge about the processes involved and therefore to develop a better understanding of the behaviour of the soil system as a whole. They are useful in formulating and testing 
hypotheses and in establishing the relative importance of parameters.

Most models on soil organic matter distinguish different pools, each representing material with a different stability with regard to decomposition (Parnas, 1974; Jenkinson \& Rayner, 1977; Frissel \& van Veen, 1981; Paustian, 1987). Although adequate methods to experimentally establish the partitioning of soil organic matter over these different pools are still lacking, this approach seems the most promising to describe soil organic matter dynamics on a field scale (Jenkinson \& Rayner, 1977).

Differences in total net mineralization of labelled substrates between soils of different texture have been observed (Sorensen, 1981; van Veen et al., 1985). Net mineralization and immobilization are more rapid in sandy soils than in clay soils (Hassink, unpublished), and, generally, soils with a higher clay content have a higher organic matter content (Kortleven, 1963). The lower net mineralization in clay soils which leads to a higher organic matter content, is assumed to be caused by physical protection of soil organic matter and microbial biomass. Indications that soil particles provide protection against microbial decomposition are obtained from the observed large differences between turnover rate of particular compounds in liquid microbial cultures and in soils (van Veen \& Paul, 1981), and indirectly from data showing that disruption of soil results in an increase in mineralization of both carbon and nitrogen (Gregorich et al., 1989). Apparently, the protection of part of the organic matter against microbial attack is lowered by the disruption of the soil. Sorensen (1975) already observed that the extent of protection varied with the degree of aggregation and clay content. The stabilizing effect is assumed to be the result of adsorption of organic material by layers in swelled clays, adsorption on the surface of silt and clay particles, or aggregate formation, which renders the organic material less accessible to decomposition by microorganisms.

We designed a computer model to simulate soil organic matter dynamics based on the models of van Veen (van Veen \& Paul, 1981; van Veen et al., 1984; van Veen et al., 1985) as a first step toward simulating the effects of soil type on nitrogen mineralization. Most published models are used to describe and simulate field situations. The purpose of the present study is to analyse and explain model behaviour, with respect to both short-term and long-term effects, in order to increase insight in soil organic matter dynamics. Attention is paid to several aspects:

- carbon (C) and nitrogen (N) cycling in the soil,

- the role of native soil organic matter and added organic material in soil fertility and nitrogen availability to the crop,

- identification of key soil properties that would allow to differentiate between mineralization and immobilization of different soil types (clay and sandy soils). The final goal of the model is to predict (daily) net mineralization of different soils.

\section{Model description}

Figure 1 shows the flow chart of the model. The main partition of organic matter is over recently added organic materials such as crop residues and manure, and native soil organic matter. Both are further subdivided into different components. 


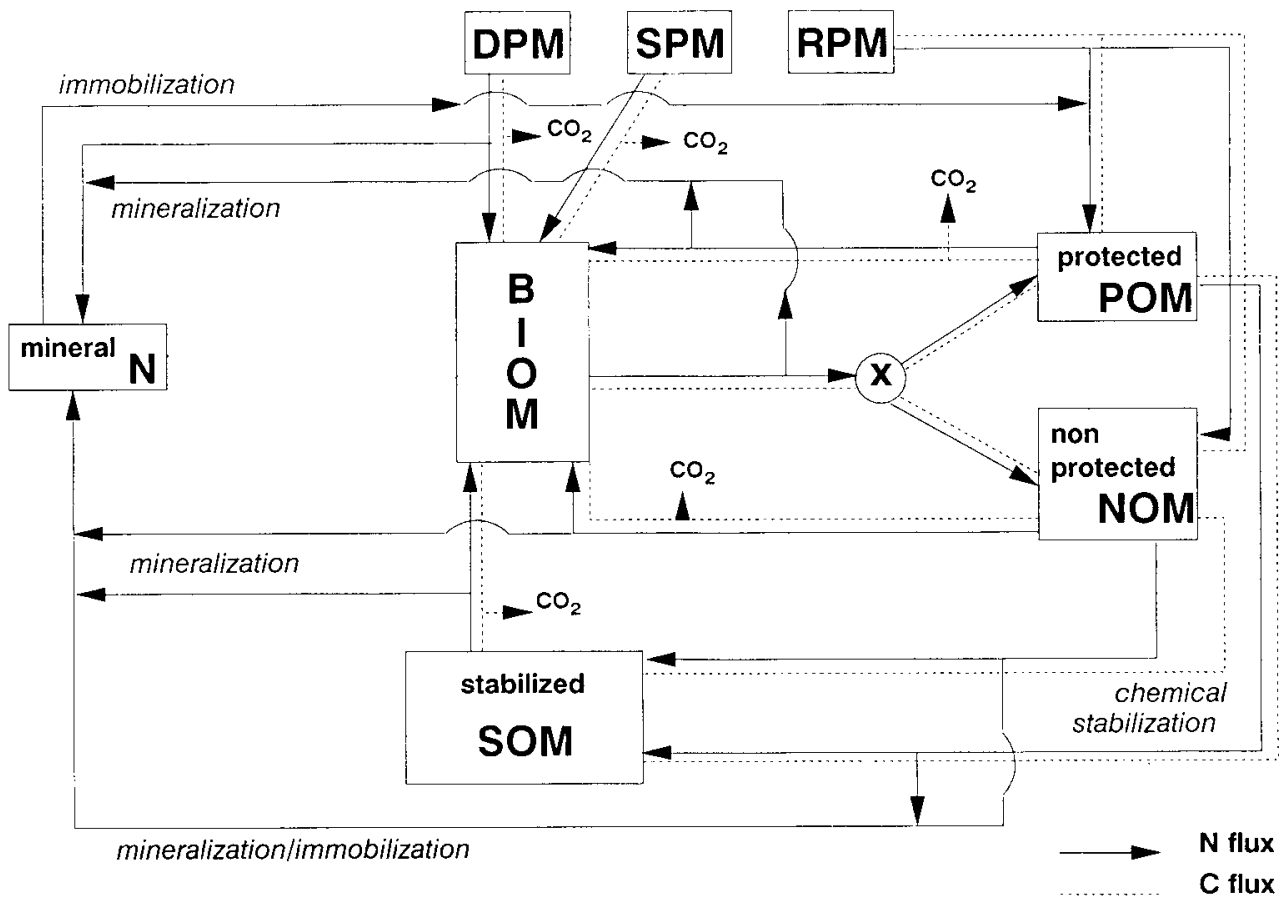

Fig. 1 Flow-chart of the model. The state variables (DPM: decomposable material, SPM: structural material, RPM: resistant material, BIOM: microbial biomass, POM: protected soil organic matter, NOM: nonprotected soil organic matter, SOM: stabilized soil organic matter), which characterize and quantify all properties that describe the state of the system, are represented by rectangles and the flows of material by solid (nitrogen) and dotted (carbon) lines.

\section{Residues}

Residues are considered to consist of three fractions each with its own resistance to biological decomposition (van Veen \& Paul, 1981):

(1) decomposable material (DPM), i.e. carbohydrates and proteins,

(2) structural material (SPM), i.e. cellulose and hemicellulose,

(3) resistant material (RPM), i.e. lignified structural material.

Each fraction is assumed to have a fixed carbon:nitrogen ratio $\left((\mathrm{C} / \mathrm{N})_{\mathrm{dpm}}\right.$, $(\mathrm{C} / \mathrm{N})_{\mathrm{spm}}$ and $\left.(\mathrm{C} / \mathrm{N})_{\mathrm{rpm}}\right)$. The overall $\mathrm{C} / \mathrm{N}$ ratio of the residue is the weighted mean of the three fractions. A high fraction of decomposable material $\left(F_{\mathrm{dpm}}\right)$ results in a low overall $\mathrm{C} / \mathrm{N}$ ratio, a high fraction of structural $\left(F_{\mathrm{spm}}\right)$ and/or resistant material $\left(F_{\mathrm{rpm}}\right)$ in a high value.

Decomposable and structural material (DPM, SPM) are considered to be decomposed by the microbial biomass, while the lignin fraction (RPM) directly enters the soil organic matter pool. This enables the description of the role of ligneous compounds in the chemical stabilization of organic matter in soil (Swift et al., 1979). 


\section{Soil organic matter}

Soil organic matter is divided into three major fractions (Fig. 1): microbial biomass (BIOM), active organic matter (POM plus NOM) and stabilized organic matter (SOM), an old inactive fraction stabilized by unspecified mechanisms (van Veen et al., 1984).

Active organic matter is divided into a physically protected component (POM) and a nonprotected component (NOM). As protection against decomposition appears more effective in soils with a high clay and silt content (lower nitrogen mineralization (Hassink, unpublished), in these soils a higher protection of the active soil organic matter is assumed to be physically protected.

\section{Microbial biomass}

Soil microbial biomass is also divided into a protected and a nonprotected component (van Veen et al., 1984). It is assumed that each soil has a specific maximum capacity to protect microorganisms, which is roughly equal to the size of the microbial biomass present in a soil not recently disturbed, e.g. by tillage or large additions of fresh organic material. Microbial biomass has been shown to be positively correlated with total organic carbon (Schnurer et al., 1985; Theng et al., 1989 ), and therefore, the maximum capacity to protect microorganisms $\left(C_{\mathrm{B}, \max }\right)$ is defined as a fraction of the total organic soil carbon $\left(C_{\mathrm{T}}\right)$ (Theng et al., 1989). Evidence for the existence of such a maximum protective capacity is derived from the common observation of a sharp increase in microbial biomass upon addition of carbon compounds, followed by a steep decline to the original level (van Veen et al., 1984). In the model, we assume that the microbial biomass in excess of the maximum protective capacity of the soil is subject to rapid turnover, whereas the protected microbial biomass is assumed to have a hundredfold lower turnover time.

$$
\begin{aligned}
C_{\mathrm{B}} \geq C_{\mathrm{B}, \max }: \begin{array}{l}
C_{\mathrm{B}, \mathrm{P}}=C_{\mathrm{B}, \max } \\
C_{\mathrm{B}, \mathrm{n}}=C_{\mathrm{B}}-C_{\mathrm{B}, \max }
\end{array} \\
C_{\mathrm{B}} \leq C_{\mathrm{B}, \max }: \begin{array}{l}
C_{\mathrm{B}, \mathrm{P}}=C_{\mathrm{B}} \\
C_{\mathrm{B}, \mathrm{n}}=0
\end{array}
\end{aligned}
$$

where $C_{\mathrm{B}}=$ total microbial biomass, $C_{\mathrm{B}, \mathrm{n}}=$ nonprotected microbial biomass, and $C_{\mathrm{B}, \mathrm{P}}=$ protected microbial biomass.

\section{Carbon and nitrogen fluxes}

All transformations are considered to be first-order reactions, on the assumption that the concentration of the material involved rather than the biological capacity is rate-limiting in decompostion (van Veen \& Paul, 1981).

This implies that the rate of substrate decomposition $D_{\mathrm{C}}\left(\mathrm{kg} \mathrm{C} \mathrm{ha-1}^{-1}\right)$ is 


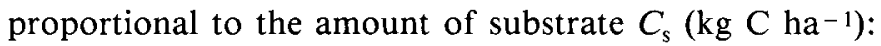

$$
D_{\mathrm{C}}=\frac{\mathrm{d} C_{\mathrm{s}}}{\mathrm{d} t}=k \times C_{\mathrm{s}}
$$

Where $k$ is the first-order decomposition rate constant $\left(\mathrm{d}^{-1}\right)$ and $t$ is time (d).

Each transformation indicated in Figure 1 has a specific decomposition rate constant $(k)$ and a yield efficiency factor $(E)$, defining the fraction of the decomposing material incorporated into microbial biomass $C_{\mathrm{B}}(\mathrm{kg} \mathrm{C}$ ha-1). The remainder $(1-E)$ leaves the system as $\mathrm{CO}_{2}$. The growth rate of microbial biomass, $G_{\mathrm{C}}(\mathrm{kg} \mathrm{C}$ $\left.\mathrm{ha}^{-1} \mathrm{~d}^{-1}\right)$, and the rate of respiration $\left(\mathrm{kg} \mathrm{C} \mathrm{ha}^{-1} \mathrm{~d}^{-1}\right)$ are described by:

$$
\begin{aligned}
& G_{\mathrm{C}}=\frac{\mathrm{d} C_{\mathrm{B}}}{\mathrm{d} t}=E \times k \times C_{\mathrm{s}} \\
& \frac{\mathrm{d} C O_{2}}{\mathrm{~d} t}=D_{\mathrm{C}}-G_{\mathrm{C}}=(1-E) \times k \times C_{\mathrm{s}}
\end{aligned}
$$

The decomposition rate constants $(k)$ and efficiency factors $(E)$ are assumed to be independent of the kind of residue and soil type. It is outside the scope of this study to investigate the effects of all environmental factors like temperature, soil moisture content, gaseous atmosphere composition, soil $\mathrm{pH}$, and their interactions. Suboptimal conditions are taken into account using reduction factors for the rates of decomposition, with values between 0 (complete inhibition) and 1 (optimum conditions) (van Veen \& Paul, 1981).

The rates of decomposition for structural (SPM) and resistant (RPM) material are calculated as a function of the fraction of resistant material, according to Parton et al. (1987):

$$
\begin{aligned}
& k_{2}=k_{2 \mathrm{~m}} \times \exp \left(-3.0 \times \frac{F_{\mathrm{rpm}}}{F_{\mathrm{spm}}+F_{\mathrm{rpm}}}\right) \\
& k_{3}=k_{3 \mathrm{~m}} \times \exp \left(-3.0 \times \frac{F_{\mathrm{rpm}}}{F_{\mathrm{spm}}+F_{\mathrm{rpm}}}\right)
\end{aligned}
$$

where $k_{2 \mathrm{~m}}$ and $k_{3 \mathrm{~m}}$ are the maximum relative decomposition rates for structural and resistant material, respectively. Both rates of decomposition decrease as the lignin component $\left(F_{\mathrm{rpm}}\right)$ increases; that is based on the assumption that as the lignin component increases the accessibility, and thus the decomposability of structural materials such as hemicellulose and cellulose decrease rapidly (Swift et al., 1979). Lignin and (hemi)cellulose are closely related within cell walls and although there is probably no chemical interaction between the two, lignin is released as the microbes decompose (hemi)cellulose. The resistant material is distributed in a 1:1 ratio between the nonprotected (NOM) and the protected (POM) organic matter.

Decomposing microbial biomass is also distributed between the nonprotected and the protected organic matter; the actual distribution is governed by a soil-type 
specific parameter $\alpha_{\mathrm{p}}$. The proportion of carbon and nitrogen released during decomposition of dead microbial biomass, retained near protected organic matter is higher in clay soils than in sandy soils. Hence, the value of $\alpha_{\mathrm{P}}$ is higher for soils with a high clay content, resulting in a larger proportion of carbon and nitrogen from decomposing microbial biomass into the protected (POM) organic matter pool.

The nitrogen fluxes are assumed to be proportional to the carbon fluxes. The rate of nitrogen release $D_{\mathrm{N}}\left(\mathrm{kg} \mathrm{N} \mathrm{a}^{-1} \mathrm{~d}^{-1}\right)$ thus depends on the $\mathrm{C} / \mathrm{N}$ ratio of the substrate $\left((\mathrm{C} / \mathrm{N})_{\mathrm{s}}\right)$, whereas the growth rate of microbial biomass-N $G_{\mathrm{N}}\left(\mathrm{kg} \mathrm{N} \mathrm{ha}^{-1}\right.$ $\left.\mathrm{d}^{-1}\right)$ depends on the $\mathrm{C} / \mathrm{N}$ ratio of the microbial biomass $\left((\mathrm{C} / \mathrm{N})_{\mathrm{B}}\right)$.

$$
\begin{aligned}
D_{\mathrm{N}} & =\frac{k \times C_{\mathrm{s}}}{(\mathrm{C} / \mathrm{N})_{\mathrm{s}}} \\
G_{\mathrm{N}} & =\frac{E \times k \times C_{\mathrm{s}}}{(\mathrm{C} / \mathrm{N})_{\mathrm{B}}}
\end{aligned}
$$

If $1 /(\mathrm{C} / \mathrm{N})_{\mathrm{s}}>E /(\mathrm{C} / \mathrm{N})_{\mathrm{B}}$, net mineralization $\left(N_{\min }>0, \mathrm{~kg} \mathrm{~N} \mathrm{ha}^{-1} \mathrm{~d}^{-1}\right)$ occurs:

$$
N_{\min }=k \times C_{\mathrm{s}} \times\left(\frac{1}{(\mathrm{C} / \mathrm{N})_{\mathrm{s}}}-\frac{E}{(\mathrm{C} / \mathrm{N})_{\mathrm{B}}}\right)
$$

In the reverse condition, net immobilization is the result.

\section{Model formulation}

The concepts outlined so far result in the following equations for the rates of change of the different state variables. $C_{\text {inp }}\left(\mathrm{kg} \mathrm{C} \mathrm{ha}^{-1} \mathrm{~d}^{-1}\right)$ is the (daily) residue input; all other symbols are explained in the preceding text, Figure 1, and Tables 1a and $1 \mathrm{~b}$. The rate of decomposition of the various components of residues is described as (see (3)):

$$
\begin{aligned}
& \frac{\mathrm{d} C_{\mathrm{dpm}}}{\mathrm{d} t}=-k_{1} \times C_{\mathrm{dpm}}+F_{\mathrm{dpm}} \times C_{\mathrm{inp}} \\
& \frac{\mathrm{d} C_{\mathrm{spm}}}{\mathrm{d} t}=-k_{2} \times C_{\mathrm{spm}}+F_{\mathrm{spm}} \times C_{\mathrm{inp}} \\
& \frac{\mathrm{d} C_{\mathrm{rpm}}}{\mathrm{d} t}=-k_{3} \times C_{\mathrm{rpm}}+F_{\mathrm{rpm}} \times C_{\mathrm{inp}}
\end{aligned}
$$

The rates of change in the amount of carbon in microbial biomass $\mathrm{d} C_{\mathrm{B}} / \mathrm{d} t(\mathrm{~kg} \mathrm{C}$ $\left.\mathrm{ha}^{-1} \mathrm{~d}^{-1}\right)$, nonprotected soil organic matter $\mathrm{d} C_{\mathrm{N}} / \mathrm{d} t\left(\mathrm{~kg} \mathrm{C} \mathrm{ha}^{-1} \mathrm{~d}^{-1}\right)$, protected soil organic matter $\mathrm{d} C_{\mathrm{P}} / \mathrm{d} t\left(\mathrm{~kg} \mathrm{C} \mathrm{ha}^{-1} \mathrm{~d}^{-1}\right)$, and stabilized soil organic matter $\mathrm{d} C_{\mathrm{s}} / \mathrm{d} t$ $\left(\mathrm{kg} \mathrm{C} \mathrm{ha-1}^{-1} \mathrm{~d}^{-1}\right.$, respectively, are described by: 


$$
\begin{aligned}
\frac{\mathrm{d} C_{\mathrm{B}}}{\mathrm{d} t}= & E_{1} \times k_{1} \times C_{\mathrm{dpm}}+E_{2} \times k_{2} \times C_{\mathrm{spm}}+E_{5} \times k_{5} \times C_{\mathrm{N}}+E_{6} \times k_{6} \times C_{\mathrm{P}}+ \\
& E_{7} \times k_{7} \times C_{\mathrm{s}}-k_{4 \mathrm{P}} \times C_{\mathrm{B}, \mathrm{P}}-k_{4 \mathrm{~N}} \times C_{\mathrm{B}, \mathrm{n}} \\
\frac{\mathrm{d} C_{\mathrm{N}}}{\mathrm{d} t}= & 0.5 \times E_{3} \times k_{3} \times C_{\mathrm{rpm}}+\left(1-\alpha_{\mathrm{P}}\right) \times E_{4} \times\left(k_{4 \mathrm{P}} \times C_{\mathrm{B}, \mathrm{P}}+k_{4 \mathrm{n}} \times C_{\mathrm{B}, \mathrm{n}}\right)- \\
& \left(k_{5}+k_{8}\right) \times C_{\mathrm{N}} \\
\frac{\mathrm{d} C_{\mathrm{P}}=}{\mathrm{d} t} & 0.5 \times E_{3} \times k_{3} \times C_{\mathrm{rpm}}+\alpha_{\mathrm{P}} \times E_{4} \times\left(k_{4 \mathrm{P}} \times C_{\mathrm{B}, \mathrm{P}}+k_{4 \mathrm{n}} \times C_{\mathrm{B}, \mathrm{n}}\right)- \\
& \left(k_{6}+k_{9}\right) \times C_{\mathrm{P}} \\
\frac{\mathrm{d} C_{\mathrm{S}}=}{\mathrm{d} t} & E_{8} \times k_{8} \times C_{\mathrm{N}}+E_{9} \times k_{9} \times C_{\mathrm{P}}-k_{7} \times C_{\mathrm{s}}
\end{aligned}
$$

\section{Parameter values}

Standard values for model parameters are given in Table la (optimum temperature $\left(25^{\circ} \mathrm{C}\right)$ and moisture). Most of the parameter values are obtained from the literature (van Veen \& Paul, 1981; van Veen et al., 1984; van Veen et al., 1985).

For transformations without microbial interference the yield efficiency factor is by definition 1 . In the model this applies to the flow of resistant material to nonprotected and protected organic matter $\left(E_{3}=1\right)$, the flow of microbial products to nonprotected and protected organic matter $\left(E_{4}=1\right)$, and the transformation of nonprotected and protected organic matter into stabilized organic matter $\left(E_{8}=1\right.$, $E_{9}=1$ ).

Physical protection leads to a decrease in rate of decomposition. The rate of decomposition of protected microbial biomass $\left(k_{4 \mathrm{P}}\right)$ is set rather low: $0.005 \mathrm{~d}^{-1}$ (inactive population with a relatively low maintenance requirement) and is of the same order of magnitude as the turnover time for microbial biomass used by Jenkinson \& Parry (1989). Microbial biomass formed in excess of soil protection capacity is assumed to decompose at a much higher rate $\left(k_{4 \mathrm{n}}=0.5 \mathrm{~d}^{-1}\right.$, active population with a relatively high maintenance requirement). The rate of decomposition of protected organic matter $\left(k_{6}\right)$ is set at 0.03 times that of nonprotected organic matter $\left(k_{5}\right)$ on the basis of the results of simulation studies of the transformation of simple amino acids in soils (Paul \& van Veen, 1978). Stabilized organic matter has a turnover time of the order of 1000 years or more, as indicated by ${ }^{14} \mathrm{C}$-dating (Paul \& van Veen, 1978).

The $\mathrm{C} / \mathrm{N}$ ratios of the state variables are assumed to be constant. For decomposable material $\left((\mathrm{C} / \mathrm{N})_{\mathrm{dpm}}\right)$ it is set at 6 (overall $\mathrm{C} / \mathrm{N}$ ratio of carbohydrates and proteins), for structural material $\left((\mathrm{C} / \mathrm{N})_{\mathrm{spm}}\right)$ at 150 (Parton et al., 1987), and for resistant material $\left((\mathrm{C} / \mathrm{N})_{\mathrm{rpm}}\right)$ at 100 (lignified material, Whitmore \& Parry, 1988). The 


\section{Model behaviour}

Steady state solutions in a constant environment

In a steady state the total flux into each state variable equals the total flux out of that state variable. In the steady state of this model, carbon input by residues is in balance with carbon output by respiration, and nitrogen input by residues is in balance with nitrogen output by net mineralization.

Although steady state conditions are never reached in practical agriculture nor in field experiments, in a model it usually provides the best means of exploring and understanding a complex system. For models with a single steady state condition (such as the present model under the applied conditions), the steady state values are independent of the initial conditions.

Analytically, the steady state values for the state variables follow from Equations $(11)-(17)$ by setting the left-hand side to zero, and solving the equations for the seven variables:

$$
\begin{aligned}
& C_{\mathrm{dpm}}=\frac{F_{\mathrm{dpm}} \times C_{\mathrm{inp}}}{k_{1}} \\
& C_{\mathrm{spm}}=\frac{F_{\mathrm{spm}} \times C_{\mathrm{inp}}}{k_{2}} \\
& C_{\mathrm{rpm}}=\frac{F_{\mathrm{rpm}} \times C_{\mathrm{inp}}}{k_{3}} \\
& C_{\mathrm{B}}-C_{\mathrm{B}, \max }=\left[-E_{1} \times F_{\mathrm{dpm}} \times C_{\mathrm{inp}}-E_{2} \times F_{\mathrm{spm}} \times C_{\mathrm{inp}}+k_{4 \mathrm{p}} \times C_{\mathrm{B}, \max }-\right. \\
& \frac{\left(0.5 \times E_{3} \times F_{\mathrm{rpm}} \times C_{\mathrm{inp}}\right)+\left(1-\alpha_{\mathrm{p}}\right) \times E_{4} \times k_{4 \mathrm{p}} \times C_{\mathrm{B}, \max } \times\left(E_{5} \times k_{5}+E_{7} \times E_{8} \times k_{8}\right)}{k_{5}+k_{8}} \\
& \left.-\frac{\left(0.5 \times E_{3} \times F_{\mathrm{rpm}} \times C_{\mathrm{inp}}\right)+\alpha_{\mathrm{p}} \times E_{4} \times k_{4 \mathrm{p}} \times C_{\mathrm{B}, \text { max }} \times\left(E_{6} \times k_{6}+E_{7} \times E_{9} \times k_{9}\right)}{k_{6}+k_{9}}\right] / \\
& {\left[-k_{4 \mathrm{n}}+\frac{\left(1-\alpha_{\mathrm{p}}\right) \times E_{4} \times k_{4 \mathrm{n}} \times\left(E_{5} \times k_{5}+E_{7} \times E_{8} \times k_{8}\right)}{k_{5}+k_{8}}+\right.} \\
& \left.\frac{\alpha_{\mathrm{p}} \times E_{4} \times k_{4 \mathrm{n}} \times\left(E_{6} \times k_{6}+E_{7} \times E_{9} \times k_{9}\right)}{k_{6}+k_{9}}\right] \\
& C_{\mathrm{N}}=\frac{0.5 \times E_{3} \times F_{\mathrm{rpm}} \times C_{\mathrm{inp}}+\left(1-\alpha_{\mathrm{p}}\right) \times E_{4} \times\left(k_{4 \mathrm{p}} \times C_{\mathrm{B}, \max }+k_{4 \mathrm{n}} \times\left(C_{\mathrm{B}}-C_{\mathrm{B}, \max }\right)\right)}{k_{5}+k_{8}}
\end{aligned}
$$




$$
\begin{aligned}
C_{\mathrm{P}} & =\frac{0.5 \times E_{3} \times F_{\mathrm{rpm}} \times C_{\mathrm{inp}}+\alpha_{\mathrm{p}} \times E_{4} \times\left(k_{4 \mathrm{p}} \times C_{\mathrm{B}, \max }+k_{4 \mathrm{n}} \times\left(C_{\mathrm{B}}-C_{\mathrm{B}, \max }\right)\right)}{k_{6}+k_{9}} \\
C_{\mathrm{s}} & =\frac{E_{8} \times k_{8} \times C_{\mathrm{N}}+E_{9} \times k_{9} \times C_{\mathrm{p}}}{k_{7}} \\
C_{\mathrm{T}} & =C_{\mathrm{N}}+C_{\mathrm{P}}+C_{\mathrm{S}}+C_{\mathrm{B}}
\end{aligned}
$$

Without input, no steady state can be reached. Symbols are explained in Tables la en $1 \mathrm{~b}$. The predicted steady state of the model simulated with the $k_{\mathrm{i}}$ and $E_{\mathrm{i}}$ values of Table 1a, a carbon input $\left(C_{\text {inp }}\right)$ of $10 \mathrm{~kg} \mathrm{C} \mathrm{ha-1}^{-1} \mathrm{~d}^{-1}$ with a C/N ratio of $25\left(F_{\text {dpm }}\right.$ $=0.20, F_{\text {spm }}=0.65, F_{\mathrm{rpm}}=0.15$ ) is shown in Table $1 \mathrm{~b}$. The total amount of soil organic carbon $\left(C_{\mathrm{T}}\right)$ in a clay soil is almost twice as high as in a sandy soil; the fraction NOM is about three times higher in a sandy soil, the fraction POM and microbial biomass is lower in a sandy soil, whereas the fraction SOM is equal in

Table 2. Steady state conditions for a clay and a sandy soil with different amounts of daily carbon input

\begin{tabular}{|c|c|c|c|c|c|c|c|c|c|c|}
\hline $\begin{array}{l}C_{\text {inp }} \\
(\mathrm{kg} \mathrm{C} \\
\left.\mathrm{ha}^{-1} \mathrm{~d}^{-1}\right)\end{array}$ & $(\mathrm{C} / \mathrm{N})_{\mathrm{inp}}^{\mathrm{a}}$ & $\underset{(\mathrm{k}}{C_{\mathrm{dpm}}}$ & $\begin{array}{l}C_{\mathrm{spm}} \\
\mathrm{C}^{-1)}\end{array}$ & 1) & $\begin{array}{l}C_{\mathrm{T}} \\
(\mathrm{kg} \mathrm{C} \\
\left.\mathrm{ha}^{-1}\right)\end{array}$ & $C_{\mathrm{B}} / C_{\mathrm{T}}$ & $\begin{array}{l}C_{\mathrm{N}} / C_{\mathrm{T}} \\
\text { (fraction }\end{array}$ & $\begin{array}{l}C_{\mathrm{P}} / C_{\mathrm{T}} \\
\text { of } C_{\mathrm{T}} \text { ) }\end{array}$ & $C_{\mathrm{S}} / C_{\mathrm{T}}$ & $\begin{array}{l}\text { MIN-net } \\
(\mathrm{kg} \mathrm{N} \\
\left.\mathrm{ha}^{-1} \mathrm{~d}^{-1}\right)\end{array}$ \\
\hline \multicolumn{11}{|l|}{ Clay } \\
\hline \multirow[t]{4}{*}{10} & 20 & 30 & 184 & 153 & 52200 & 0.018 & 0.007 & 0.43 & 0.55 & 0.55 \\
\hline & 25 & 20 & 278 & 263 & 54220 & 0.018 & 0.007 & 0.43 & 0.55 & 0.39 \\
\hline & 40 & 10 & 273 & 390 & 56240 & 0.018 & 0.008 & 0.43 & 0.55 & 0.13 \\
\hline & 65 & 5 & 308 & 550 & 59000 & 0.018 & 0.008 & 0.43 & 0.55 & 0.16 \\
\hline \multirow[t]{2}{*}{5} & 25 & 10 & 114 & 132 & 27120 & 0.018 & 0.007 & 0.43 & 0.55 & 0.20 \\
\hline & 40 & 5 & 136 & 195 & 28120 & 0.018 & 0.008 & 0.43 & 0.55 & 0.12 \\
\hline 2 & 40 & 2 & 55 & 78 & 11250 & 0.018 & 0.008 & 0.43 & 0.55 & 0.05 \\
\hline \multicolumn{11}{|l|}{ Sand } \\
\hline \multirow[t]{4}{*}{10} & 20 & 30 & 184 & 153 & 28400 & 0.016 & 0.024 & 0.41 & 0.55 & 0.55 \\
\hline & 25 & 20 & 278 & 263 & 31400 & 0.016 & 0.023 & 0.41 & 0.55 & 0.39 \\
\hline & 40 & 10 & 273 & 390 & 34470 & 0.016 & 0.021 & 0.42 & 0.55 & 0.13 \\
\hline & 65 & 5 & 308 & 550 & 37820 & 0.016 & 0.020 & 0.42 & 0.55 & 0.16 \\
\hline \multirow[t]{2}{*}{5} & 25 & 10 & 114 & 132 & 15720 & 0.016 & 0.023 & 0.41 & 0.55 & 0.20 \\
\hline & 40 & 5 & 136 & 195 & 17230 & 0.016 & 0.021 & 0.42 & 0.55 & 0.12 \\
\hline 2 & 40 & 2 & 55 & 78 & 6900 & 0.016 & 0.021 & 0.42 & 0.55 & 0.05 \\
\hline
\end{tabular}
$\left(C_{\text {inp }}\right)$ and different types of residue $\left((\mathrm{C} / \mathrm{N})_{\text {inp }}\right)$. Symbols are explained in Tables 1a and $1 \mathrm{~b}$. MIN-net is net mineralization.

a $\mathrm{C} / \mathrm{N}$ ratio 20: $F_{\mathrm{dpm}}=0.30, F_{\mathrm{spm}}=0,60, F_{\mathrm{rpm}}=0.10$

$\mathrm{C} / \mathrm{N}$ ratio $25: F_{\mathrm{dpm}}=0.20, F_{\mathrm{spm}}=0.65, F_{\mathrm{rpm}}=0.15$

$\mathrm{C} / \mathrm{N}$ ratio $40: F_{\mathrm{dpm}}=0.10, F_{\mathrm{spm}}=0.70, F_{\mathrm{rpm}}=0.20$

C/N ratio 65: $F_{\mathrm{dpm}}=0.05, F_{\mathrm{spm}}=0.70, F_{\mathrm{rpm}}=0.25$ 


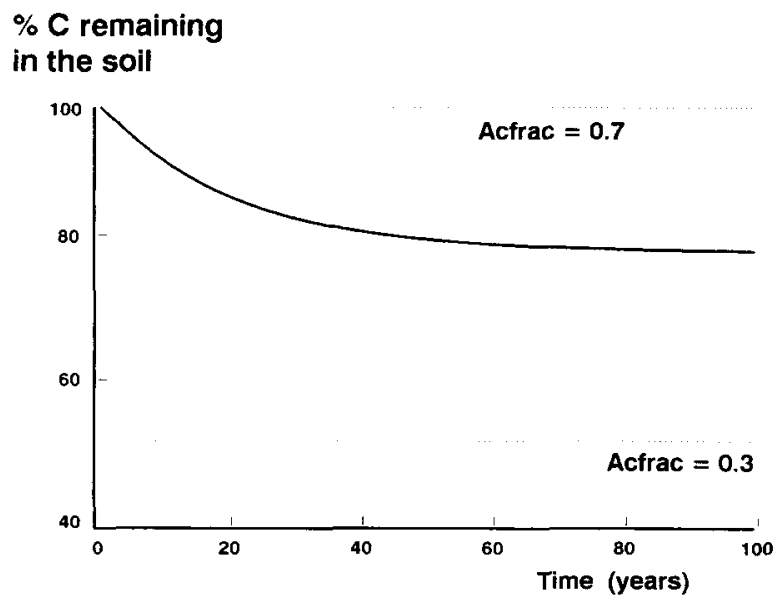

Fig. 2 Effect of changing the parameter $\alpha_{\mathrm{p}}$ from 0.7 to 0.3 (solid line) on the total $\mathrm{C}$ content of a soil (with a constant input of $10 \mathrm{~kg} \mathrm{C} \mathrm{ha-1}^{-1} \mathrm{~d}^{-1}$ ). The upper dotted line shows the steady state situation of a clay soil $\left(\alpha_{\mathrm{p}}\right.$ is 0.7$)$ and the lower dotted line that of a sandy soil $\left(\alpha_{\mathrm{p}}\right.$ is 0.3$)$.

both soils. The steady state value of the fraction BIOM is the maximum capacity of the soil to protect microorganisms.

Table 2 shows steady state conditions for a clay and a sandy soil for different amounts of daily carbon input and different types of residues. A lower input results in a lower total amount of soil organic carbon $\left(C_{\mathrm{T}}\right)$ and a lower net mineralization (MIN-net). The absolute value of all state variables decreases with a lower input, without affecting their distribution. Application of residues with a high fraction of lignin leads to a slightly higher level of soil organic carbon. Daily net mineralization is higher with higher proportions of DPM.

The effect of $\alpha_{\mathrm{p}}$, governing the distribution of carbon from decomposing microbial biomass between the protected and nonprotected soil organic matter, on total soil organic carbon is shown in Figure 2. Lowering the value $\alpha_{\mathrm{p}}$ from 0.7 to 0.3 results in a decrease in total soil organic carbon because the nonprotected soil organic matter has a rapid turnover. In the new steady state situation the fraction of protected soil organic matter is smaller and the fraction of nonprotected soil organic matter larger. The steady state value of the fraction of stabilized soil organic matter is independent of $\alpha_{\mathrm{p}}$. The new equilibrium situation for the active soil organic matter is reached in approximately 100 years. It will take more than 1000 years to reach the final steady state, due to the much longer time constant of the stabilized soil organic matter.

\section{Transient solutions in a constant environment}

To examine the influence of soil type on nitrogen mineralization and immobilization, simulation runs were carried out in a constant environment. In the model, a sandy and clay soil only differ in $\alpha_{\mathrm{p}}$ (Fig. 2). Figure 3a shows cumulative net 


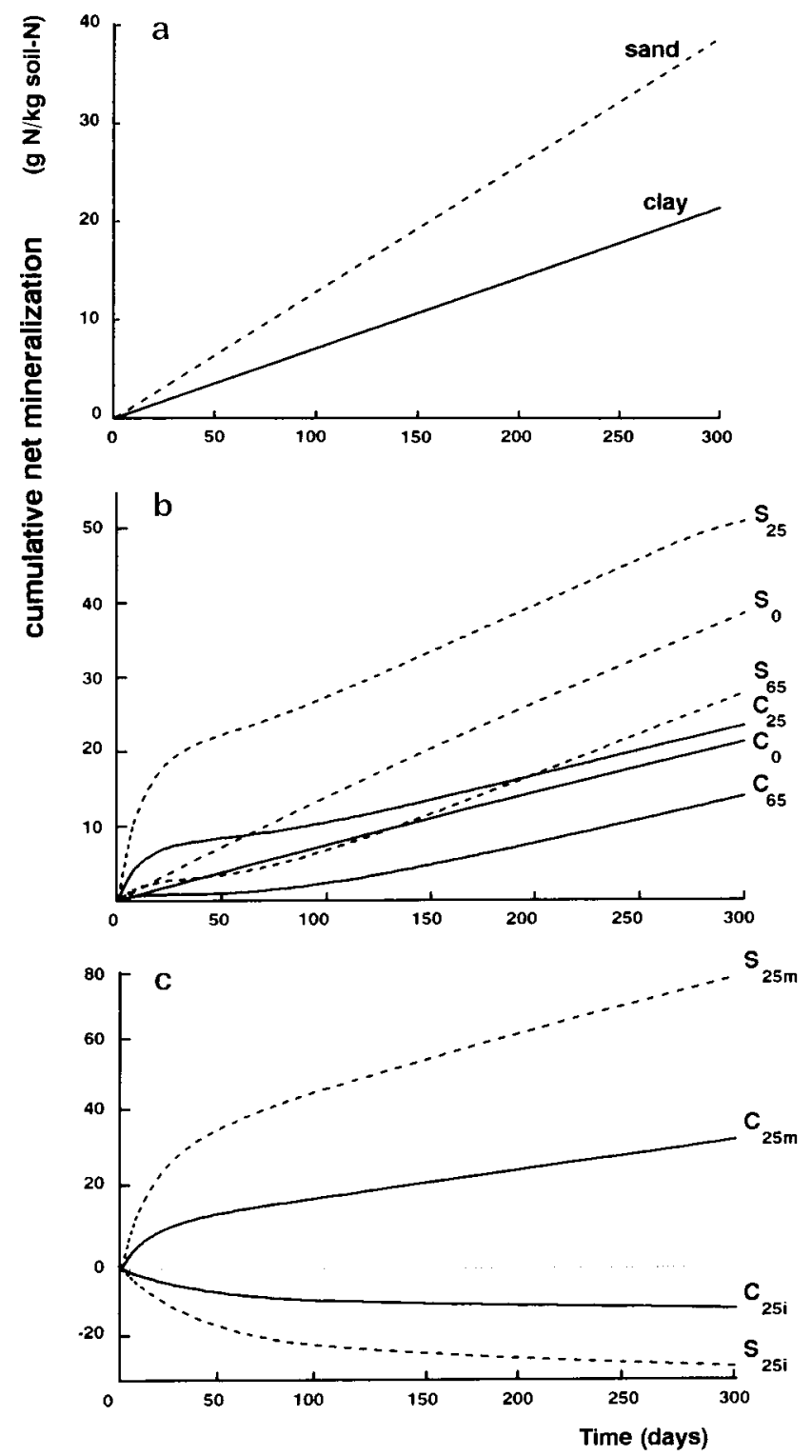

Fig. 3 (a) Cumulative net mineralization for a period of 300 days in a sandy (dotted line) and a clay soil (solid line) without residue input. (b) Cumulative net mineralization in clay soils and sandy soils for a period of 300 days without input or with an input of $2000 \mathrm{~kg} \mathrm{C} \mathrm{ha-1}$ and a $\mathrm{C} / \mathrm{N}$ ratio of 25 or 65 . $\mathrm{C}_{0}$ : clay soil, no input; $\mathrm{S}_{0}$ : sandy soil, no input; $\mathrm{C}_{25}$ : clay soil, $\mathrm{C} / \mathrm{N}=25\left(F_{\mathrm{dpm}}=0.20, F_{\mathrm{spm}}=0.65, F_{\mathrm{rpm}}\right.$ $=0.15) ; \mathrm{S}_{25}$ : sandy soil, $\mathrm{C} / \mathrm{N}=25\left(F_{\mathrm{dpm}}=0.20, F_{\mathrm{spm}}=0.65, F_{\mathrm{rpm}}=0.15\right) ; \mathrm{C}_{65}$ : clay soil, $\mathrm{C} / \mathrm{N}=$ $65\left(F_{\mathrm{dpm}}=0.05, F_{\mathrm{spm}}=0.70, F_{\mathrm{rpm}}=0.25\right) ; \mathrm{S}_{65}$ : sandy soil, C/N $=65\left(F_{\mathrm{dpm}}=0.05, F_{\mathrm{spm}}=0.70, F_{\mathrm{rpm}}\right.$ $=0.25$ ). (c) Cumulative mineralization and immobilization in a clay and a sandy soil for a period of 300 days both with an input of $2000 \mathrm{~kg} \mathrm{C} \mathrm{ha}^{-1}$ and a $\mathrm{C} / \mathrm{N}$ ratio of 25 for a period of 300 days. $\mathrm{C}_{25 \mathrm{~m}}$ : cumulative mineralization clay soil; $\mathrm{C}_{25 \mathrm{i}}$ : cumulative immobilization clay soil; $\mathrm{S}_{25 \mathrm{~m}}$ : cumulative mineralization sandy soil; $\mathrm{S}_{25 \mathrm{i}}$ : cumulative immobilization sandy soil. 
mineralization in a clay and a sandy soil without residue input, illustrating the higher rate in the sandy soil.

The effect of the quality of residues ( $\mathrm{C} / \mathrm{N}$ ratio 25 or 65$)$ on cumulative net mineralization in clay and sandy soils is illustrated in Figure 3b. Decomposition of residues with a $\mathrm{C} / \mathrm{N}$ ratio of 25 results in higher net mineralization whereas decomposition of residues with a $\mathrm{C} / \mathrm{N}$ ratio of 65 results in lower net mineralization compared with the situation without residue input. The release of nitrogen in both situations is higher in sandy soils. For the situation with a $\mathrm{C} / \mathrm{N}$ ratio of 25 , the contribution of mineralization and immobilization are analysed in Figure 3c. Mineralization $\left(S_{25 \mathrm{~m}}, \mathrm{C}_{25 \mathrm{~m}}\right)$ is mainly the result of decomposition of easily decomposable material (DPM) which after 30 days is practically completed; the slow increase after that, originates from native soil organic matter. The rate of nitrogen release due to decomposition of DPM is higher in the sandy soil than in the clay soil. Decomposition of structural and resistant material leads to immobilization (Fig. $3 \mathrm{c}, \mathrm{S}_{25 \mathrm{i}}$ and $\mathrm{C}_{25 \mathrm{i}}$ ), which is also higher in the sandy soil than in the clay soil. After complete decomposition of the residues the net mineralization curves run parallel to the curves referring to the situation without residue input $\left(\mathrm{S}_{0}\right.$ and $\left.\mathrm{C}_{0}\right)$.

\section{Discussion}

The model for soil organic matter dynamics presented in this paper differs from the models of van Veen (van Veen \& Paul, 1981; van Veen et al., 1984; van Veen et al., 1985) in several ways:

- only active soil organic matter is subdivided into a protected and nonprotected component,

- the nonprotected organic matter component is not subdivided into a recalcitrant and a decomposable component,

- the maximum capacity to protect microorganisms is dependent on total soil organic carbon,

- lignin compounds in residues are partitioned between nonprotected and protected organic matter,

- the proportion of lignin in residues affects accessibility and thus the rate of decomposition of structural material,

- lignin is released as microbes decompose (hemi)cellulose.

The models of van Veen were intended to describe long-term effects of cultivation and/or erosion, effects of drying and rewetting of soils, and to simulate field situations. In this study the aim is to simulate soil organic matter dynamics as a first step toward simulating the effects of soil type on nitrogen mineralization. Hence, no attempt has been made to calibrate or validate the model on the basis of field or incubation experiments; the model is descriptive rather than explanatory.

Some steady state results of Table 2 are comparable with field situations. A residue input of $10 \mathrm{~kg} \mathrm{C} \mathrm{ha}^{-1} \mathrm{~d}^{-1}$ with a C/N ratio of 25 corresponds with the input in temperate grassland (van Veen \& Paul, 1981; Swift et al., 1979), a residue input of $5 \mathrm{~kg} \mathrm{C} \mathrm{ha-1}^{-1}$ with a $\mathrm{C} / \mathrm{N}$ ratio of 40 corresponds with inputs on arable land (e.g. wheat), and a residue input of $10 \mathrm{~kg} \mathrm{Cha}^{-1} \mathrm{~d}^{-1}$ with a $\mathrm{C} / \mathrm{N}$ ratio of 65 
Table 3. Steady state results of total soil organic carbon, organic matter content and accumulated (undecomposed) surface litter $\left(C_{\mathrm{dpm}}+C_{\mathrm{spm}}+C_{\mathrm{rpm}}\right)$ simulated with different amounts of input $\left(C_{\mathrm{jnp}}\right)$ and different $\mathrm{C} / \mathrm{N}$ ratios of the input $\left((\mathrm{C} / \mathrm{N})_{\text {inp }}\right)$, for a clay and a sandy soil. The organic matter content is calculated assuming a carbon content of $58 \%$, a soil bulk density of 1000 (clay soil) and $1300 \mathrm{~kg} \mathrm{~m}^{-3}$ (sandy soil), and a rooting depth of $10 \mathrm{~cm}$.

\begin{tabular}{|c|c|c|c|c|c|}
\hline $\begin{array}{l}C_{\text {inp }} \\
(\mathrm{kg} \mathrm{C} \\
\left.\mathrm{ha}^{-1} \mathrm{~d}^{-1}\right)\end{array}$ & $(\mathrm{C} / \mathrm{N})_{\text {inp }}$ & Soil use & $\begin{array}{l}\text { Soil } \\
\text { organic } \\
\text { carbon } \\
\left(\mathrm{kg} \mathrm{C} \mathrm{ha-1)}^{-1}\right.\end{array}$ & $\begin{array}{l}\text { Organic } \\
\text { matter } \\
(\%)\end{array}$ & 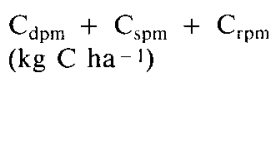 \\
\hline \multirow[t]{2}{*}{10} & \multirow[t]{2}{*}{25} & grassland (clay) & 54220 & 9.3 & 511 \\
\hline & & grassland (sand) & 31400 & 4.2 & 511 \\
\hline \multirow[t]{2}{*}{5} & \multirow[t]{2}{*}{40} & arable (clay) & 28120 & 4.8 & 336 \\
\hline & & arable (sand) & 17230 & 2.3 & 336 \\
\hline \multirow[t]{2}{*}{10} & \multirow[t]{2}{*}{65} & forest (clay) & 59000 & 10.2 & 863 \\
\hline & & forest (sand) & 37820 & 5.0 & 863 \\
\hline
\end{tabular}

corresponds with a temperate forest (Swift et al., 1979; Staaf \& Berg, 1980). Table 3 shows the simulated steady states in terms of total soil organic carbon, soil organic matter content and amounts of accumulated surface litter $\left(C_{\mathrm{DPM}}+C_{\mathrm{SPM}}+C_{\mathrm{RPM}}\right)$ of these various agricultural systems. Organic matter content of a clay soil is higher than of a sandy soil, and is higher under grassland and forest than under arable cropping. Kortleven (1963) already reported that the soil organic matter content under grassland is, on average, two to five times higher than under arable cropping and it increases with clay and silt content of the soil. The results of the steady state simulations indicate that returning residues to soils helps to maintain soil organic matter content and soil fertility in terms of nitrogen mineralization.

It has often been observed that decomposition of residues and nitrogen mineralization is slower in soils with heavier texture (Jenkinson, 1977; van Veen et al., 1985), and mineralization of native soil organic nitrogen is also slower in clay than in sandy soils (Hassink, unpublished). The pattern of nitrogen mineralization of different residues in different soils is similar, as illustrated in Figures 3a en 3b. During the first 15 days, a rapid increase in mineral nitrogen is calculated in both soils when residues with a low $\mathrm{C} / \mathrm{N}$ ratio are decomposed, due to the removal (outwash) of soluble components like carbohydrates and proteins and microbial decomposition of simple organic compounds (Swift, 1985). After 20 days, the release of nitrogen decreases during decomposition of structural and resistant material, both with a low nitrogen content. The net mineralization of nitrogen from similar residues is higher in the sandy soil than in the clay soil. This is due to the higher fraction of nonprotected organic matter with a relatively high turnover rate. This is illustrated in Table 4, showing the relative contribution of the various fractions to nitrogen mineralization for both soil types for a period of 300 days, and the percentage nitrogen in those various soil organic matter pools. Although the nonprotected organic nitrogen is a very small fraction of total soil nitrogen, its contribution to mineralization is considerable, especially in the sandy soil. Without input, protected soil or- 
Table 4. Nitrogen in the various soil organic matter components as a percentage of total soil organic nitrogen, and the relative contribution of the components to nitrogen mineralization for a clay and a sandy soil. Mineralization is calculated with the model for a period of 300 days.

\begin{tabular}{|c|c|c|c|c|}
\hline & \multirow{3}{*}{$\begin{array}{l}\% \text { of } \\
\text { soil } N\end{array}$} & \multicolumn{3}{|c|}{ Relative contribution to mineralization ( $\%$ ) } \\
\hline & & \multirow[t]{2}{*}{ no input } & \multicolumn{2}{|c|}{ input $2000 \mathrm{~kg} \mathrm{C} \mathrm{ha-1}^{-1}$} \\
\hline & & & $\mathrm{C} / \mathrm{N}=25 \mathrm{a}$ & $\mathrm{C} / \mathrm{N}=65^{\mathrm{b}}$ \\
\hline \multicolumn{5}{|l|}{ Clay } \\
\hline BIOM & 2.2 & 18.9 & 28.0 & 25.9 \\
\hline NOM & 0.5 & 12.1 & 14.5 & 15.1 \\
\hline POM & 42.7 & 68.8 & 57.4 & 58.9 \\
\hline SOM & 54.6 & 0.2 & 0.1 & 0.1 \\
\hline \multicolumn{5}{|l|}{ Sand } \\
\hline BIOM & 2.8 & 20.5 & 36.3 & 34.0 \\
\hline NOM & 2.1 & 28.7 & 29.5 & 30.1 \\
\hline POM & 56.9 & 50.6 & 34.2 & 35.8 \\
\hline SOM & 38.2 & 0.2 & 0 & 0.1 \\
\hline
\end{tabular}

a $\mathrm{C} / \mathrm{N}$ ratio $25\left(\mathrm{~F}_{\mathrm{dpm}}=0.20, \mathrm{~F}_{\mathrm{spm}}=0.65, \mathrm{~F}_{\mathrm{rpm}}=0.15\right)$

b $\mathrm{C} / \mathrm{N}$ ratio $65\left(\mathrm{~F}_{\mathrm{dpm}}=0.05, \mathrm{~F}_{\mathrm{spm}}=0.70, \mathrm{~F}_{\mathrm{rpm}}=0.25\right)$

ganic matter (POM) provides the largest contribution to mineralization in both soils while stabilized soil organic matter (SOM) hardly contributes. Input of residues increases microbial biomass and, as a result, its contribution to mineralization. The simulated values of Table 4 agree with the results of a study by Paul \& Juma (1981), who measured the contribution of the various soil fractions to nitrogen mineralization in a loam soil. They found that the contribution of the microbial biomass was $28 \%$, of the active pool $32 \%$, of the stabilized pool $40 \%$ and of the old pool $0 \%$, close to the results presented in Table 4 for the sandy soil.

To analyse decomposition of native soil organic matter and added organic materials, and to analyse and explain differences between soils in terms of nitrogen mineralization and mineralization patterns, in mathematical models it is necessary to differentiate between specific components of native soil organic matter and residues (van Veen, 1987). Components of residues have mostly been determined by chemical methods (Goering \& van Soest, 1970); these are widely used and accepted. Less consistency exists on methods to fractionate native soil organic matter (van Veen, 1987). Hydrolysis of soil organic matter distinguishes old and young fractions, as shown by radiocarbon dating (Martel \& Paul, 1974; Paul \& van Veen, 1978). However, it is doubtful whether chemical fractionation techniques alone are sufficient to estimate the size of biologically important fractions. It is evident that the availability of organic materials as a substrate for microorganisms is not only determined by their chemical composition, but also by their spatial distribution in the soil. Observed differences in accessibility of active organic matter to biological transforma- 
tion lead to a further subdivision: an active, physically protected component and an active nonprotected component (Jenkinson \& Rayner, 1977; van Veen \& Paul, 1981; van Veen et al., 1985). Soils with a high clay and/or silt content have a high fraction of protected soil organic matter, which leads to higher total soil organic matter contents and lower net mineralization. Assuming that in a clay soil a higher proportion of the decomposing microbial biomass is retained near protected organic matter, a larger fraction moves into the protected organic matter and a smaller fraction into nonprotected organic matter, compared with a sandy soil.

The mechanism involved in protection is not yet clear. It could be adsorption at the surface of the clay minerals or location within and between soil aggregates at sites inaccessible to microorganisms. This would suggest that not only soil texture influences rate of decomposition, but also soil structure. By breaking soil structure and/or mixing the soil, e.g. under cultivation, inaccessible organic matter may become available to microorganisms. In the model the effect of cultivation can be simulated by lowering $\alpha_{\mathrm{p}}$, the proportion from decomposing microbial biomass transformed into protected soil organic matter, or by increasing the nonprotected active organic matter component (and decreasing the protected organic matter component), or a combination of the two. Figure 4 shows the effects of both changes in terms of cumulative net mineralization in both soil types. Reducing $\alpha_{\mathrm{p}}$ in a sandy soil from 0.3 to 0.1 increased cumulative net mineralization; on a clay soil a reduction of $\alpha_{\mathrm{p}}$ from 0.7 to 0.3 resulted in a stronger increase in mineralization. In

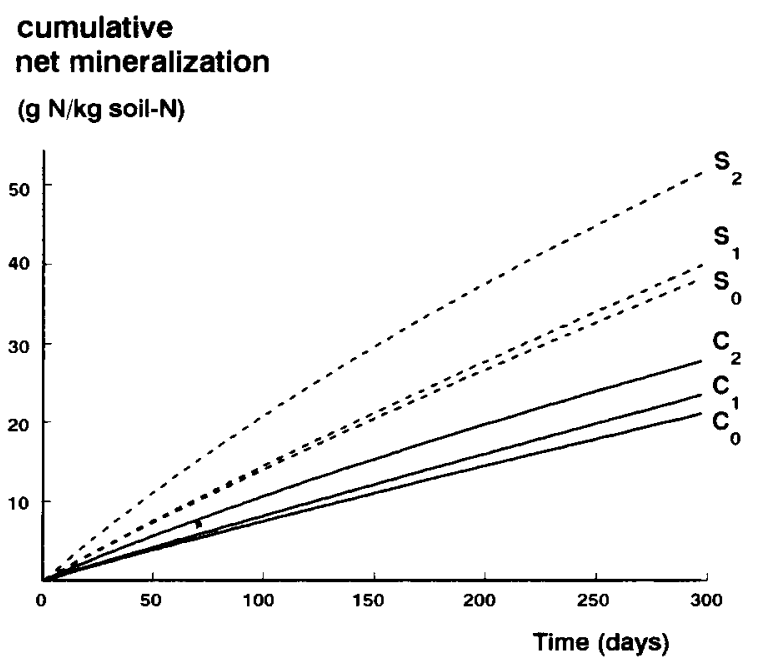

Fig. 4 Cumulative net mineralization in a clay and a sandy soil with different values of $\alpha_{\mathrm{p}}$ and different fractions active soil organic matter.

$\mathrm{S}_{0}$ : sandy soil, $\alpha_{\mathrm{p}}=0.3$, fraction $\mathrm{NOM}=0.023$, fraction $\mathrm{POM}=0.41 ; \mathrm{S}_{1}$ : sandy soil, $\alpha_{\mathrm{p}}=0.1$, fraction NOM $=0.023$, fraction $\mathrm{POM}=0.41 ; \mathrm{S}_{2}$ : sandy soil, $\alpha_{\mathrm{p}}=0.3$, fraction $\mathrm{NOM}=0.05$, fraction $\mathrm{POM}=0.383 ; \mathrm{C}_{0}$ : clay soil, $\alpha_{\mathrm{p}}=0.7$, fraction $\mathrm{NOM}=0.007$, fraction $\mathrm{POM}=0.43 ; \mathrm{C}_{1}$ : clay soil, $\alpha_{\mathrm{p}}=0.3$, fraction $\mathrm{NOM}=0.007$, fraction $\mathrm{POM}=0.43 ; \mathrm{C}_{2}$ : clay soil, $\alpha_{\mathrm{p}}=0.7$, fraction $\mathrm{NOM}=$ 0.03 , fraction $\mathrm{POM}=0.401$. 
both soils, increasing the fraction of nonprotected active organic matter has a more pronounced effect on total net mineralization than reducing $\alpha_{\mathrm{p}}$. Other effects of cultivation could be a change in environmental conditions such as higher oxygen contents which induces higher rates of decomposition and thus higher mineralization rates. In simulating the effect of cultivation (ploughing, tillage) on nitrogen mineralization, one has to take all these factors into account.

So far, the parameter $\alpha_{\mathrm{p}}$ describing the partitioning between nonprotected and protected active organic matter was used as a key parameter to characterize the effect of soil type on decomposition. In further model development, the significance of $\alpha_{\mathrm{p}}$ could increase if the effect of other soil characteristics, like structure, porosity, surface properties and aggregation, can be incorporated. Pore size distribution could give an indication of the accessibility of substrates to decomposition by microorganisms. Pore size distribution is a function of soil texture and soil structure (Papendick \& Campbell, 1981); generally, fine-textured clay soils have a larger proportion of small pores. Changing soil structure, e.g. by cultivation, may change pore size and pore size distribution.

In developing the model, it was attempted to increase insight in soil organic matter dynamics of different soils. Organic matter is undoubtedly stabilized by physical protection, which may differ substantially between soils of different texture. Different organic matter components were distinguished which at this stage constitutes a working hypothesis, which, however, was not put to a rigorous test by comparison with field data. In further development of the model particular attention will be paid to the effects of soil structure and soil texture and to the spatial distribution of organic materials and their decomposers.

\section{References}

Amato, M. \& J. N. Ladd, 1980. Studies of nitrogen immobilization and mineralization in calcareous soils. V. Formation and distribution of isotope-labelled biomass during decomposition of ${ }^{14} \mathrm{C}$ - and ${ }_{15} \mathrm{~N}$-labelled plant material. Soil Biology and Biochemistry 12: 405-411.

Anderson, D. W., S. Saggar, J. R. Bettany \& J. W. B. Stewart, 1981. Particle size fractions and their use in studies of soil organic matter: I. The nature and distribution of forms of carbon, nitrogen, and sulfur. Soil Science Society of America Journal 45: 767-772.

Cameron, R. S., \& A. M. Posner, 1979. Mineralisable organic nitrogen in soil fractionated according to particle size. Journal of Soil Science 30: 565-577.

Frissel, M. J. \& J. A. van Veen, 1981. Simulation model for nitrogen immobilization and mineralization. In: I. K. Iskandar (Ed.), Modelling wastewater renovation, p. 359-381. John Wiley \& Sons, New York.

Goering, H. K. \& P. J. van Soest, 1970. Forage fiber analysis (apparatus, reagents, procedures and some applications). Agriculture Handbook, 379, Jacket No 387-598.

Gregorich, E. G., R. G. Kachanoski \& R. P. Voroney, 1989. Carbon mineralization in soil size fractions after various amounts of aggregate disruption. Journal of Soil Science 40: 649-659.

Jenkinson, D. S., 1977. Studies on the decomposition of plant material in soils. IV. The effect of rate of addition. Journal of Soil Science 28: 417-423.

Jenkinson, D. S. \& L. C. Parry, 1989. The nitrogen cycle in the Broadbalk wheat experiment: a model for the turnover of nitrogen through the soil microbial biomass. Soil Biology and Biochemistry 21: 535-541. 
Jenkinson, D. S. \& J. H. Rayner, 1977. The turnover of soil organic matter in some of the Rothamsted classical experiments. Soil Science 123: 298-305.

Kortleven, J., 1963. Quantitative aspects of humus buildup and humus degradation. (In Dutch). Verslagen Landbouwkundige Onderzoekingen $69.1,109 \mathrm{pp}$.

Martel, Y. A. \& E. A. Paul, 1974. The use of radiocarbon dating of organic matter in the study of soil genesis. Soil Science Society of America Proceedings 38: 501-506.

Nordmeyer, H. \& J. Richter, 1985. Incubation experiments on nitrogen mineralisation in loess and sandy soils. Plant and Soil 83: 433-445.

Papendick, R. I. \& G. S. Campbell, 1981. Theory and measurement of water potential. In: Elliot, L. F., J. F. Parr \& W. R. Gardner (Eds), Water potential relations in soil microbiology, p. 1-22. Soil Science Society of America, Madison WI, USA.

Parnas, H., 1974. Model for decomposition of organic material by microorganisms. Soil Biology and Biochemistry 7: 161-169.

Parton, W. J., D. S. Schimmel, C. V. Cole \& D. S. Ojima, 1987. Analysis of factors controlling soil organic matter levels in Great Plain grasslands. Soil Science Society of America Journal 51: 1173-1179.

Paul, E. A. \& J. A. van Veen, 1978. The use of tracers to determine the dynamic nature of organic matter. Transactions 11th ISSS Congress (Edmonton), Symposia Papers, Vol. 3: 61-102.

Paul, E. A. \& N. G. Juma, 1981. Mineralization and immobilization of soil nitrogen by microorganisms. In: F. E. Clark \& T. Roswal (Eds), Terrestrial Nitrogen Cycles: Processes, Ecosystem Strategies and Management Impacts. Ecological Bulletins 33: 179-194.

Paustian, K., 1987. Theoretical analysis of C and N cycling in soil. Swedish University of Agricultural Sciences, Department of Ecology and Environmental Research, Report 30, p. 6-22.

Schnurer, J., M. Clarholm \& T. Rosswall, 1985. Microbial biomass and activity in agricultural soils with different organic matter contents. Soil Biology and Biochemistry 17: 611-618.

Sorensen, L. H., 1975. The influence of clay on the rate of decay of amino acid metabolites synthesized in soils during decomposition of cellulose. Soil Biology and biochemistry 7: 171-173.

Sorensen, L. H., 1981. Carbon-nitrogen relationship during the humification of cellulose in soils containing different amounts of clay. Soil Biology and Biochemistry 13: 313-321.

Staaf, H. \& B. Berg, 1980. Plant litter input to the soil. In: F. E. Clark \& T. Roswall (Eds), Terrestrial nitrogen cycles: Processes, ecosystem strategies and management impacts. Ecological Bulletins 33: 147-162.

Swift, M. J., 1985. Enhancement of tropical soil fertility; the role of biological research. International Soil Reference and Information Centre, Wageningen, Year Report 1985, p. 17-27.

Swift, M. J., O. W. Heal \& J. M. Anderson, 1979. Decomposition in terrestrial ecosystems. Studies in Ecology 5, p. 220-266. Blackwell, Oxford.

Theng, B. K. G., K. R. Tate \& P. Sollins, 1989. Constituents of organic matter in temperate and tropical soils. In: Coleman, D. C., J. M. Oades \& G. Uehare (Eds), Dynamics of soil organic matter in tropical ecosystems, p. 5-66. College of Tropical Agriculture and Human Resources, University of Hawaii.

Veen, J. A. van, 1987. The use of simulation models of the turnover of soil organic matter: an intermediate report. Transactions XIIIth ISSS Congress (Hamburg), Vol. 6, p. 626-635.

Veen, J. A. van \& E. A. Paul, 1981. Organic carbon dynamics in grassland soils. 1. Background information and computer simulation. Canadian Journal of Soil Science 61: 185-201.

Veen, J. A. van, J. N. Ladd \& M. J. Frissel, 1984. Modelling C an N turnover through the microbial biomass in soil. Plant and Soil 76: 257-274.

Veen, J. A. van, J. N. Ladd \& M. Amato, 1985. Turnover of carbon and nitrogen through the microbial biomass in a sandy loam and a clay soil incubated with $\left[{ }^{14} \mathrm{C}(\mathrm{U})\right]$ glucose and $\left[{ }^{15} \mathrm{~N}\right]\left(\mathrm{NH}_{4}\right) \mathrm{SO}_{4}$ under different moisture regimes. Soil Biology and Biochemistry 17: 747-756.

Whitmore, A. P. \& L. C. Parry, 1988. Computer simulation of the behaviour of nitrogen in soil and crop in the Broadbalk continuous wheat experiment. In: D. S. Jenkinson \& K. A. Smith (Eds), Nitrogen efficiency in agricultural soils, p. 418-432. Elsevier, London. 